$\mathrm{A} \int_{\text {ass }} \underset{0976-272 \times \mathrm{x}}{\mathrm{H}}$

Received : 06.09.2014

Revised : 30.10 .2014

Accepted : 12.11.2014

Members of the Research Forum

Associated Authors:

Department of Horticulture, College of Agriculture, Junagadh Agricultural University, JUNAGADH (GUJARAT)

INDIA

Author for correspondence R.V. CHAUHAN

Department of Horticulture, College of Agriculture, Junagadh Agricultural University, JUNAGADH (GUJARAT)

INDIA

Email : gskspice@gmail.com
THE ASIAN JOURNAL OF HORTICULTURE

Volume 9 | Issue 2 | Dec., 2014 |404-407

Visit us -www.researchjournal.co.in

\title{
Effect of gibberellic acid on flowering and cut flower yield in gerbera under protected condition
}

\section{R.V. CHAUHAN, K.P. KAVA ${ }^{1}$, V.J. BABARIYA ${ }^{1}$, P.B. PANSURIA ${ }^{1}$ AND A.B. SAVALIYA ${ }^{1}$}

ABSTRACT : An experiment was conducted to study the effect of gibberellic acid on flowering and cut flower yield in gerbera $\mathrm{cv}$. ALCOCHETE under protected condition using various gibberellic acid levels viz., $\mathrm{GA}_{3}$ at 50, 100 and $150 \mathrm{ppm}$. The experiment was conducted in Completely Randomized Block Design with three replications. The results revealed that $\mathrm{GA}_{3}$ at $100 \mathrm{ppm}$ performed better for flowering span (138.75 days), length of flower stalk $(54.32 \mathrm{~cm})$, flower stalk thickness $(6.28 \mathrm{~cm})$, number of ray florets per flower (189.67). In case of yield parameters, the same treatment was found better for fresh and dry weight of cut flower (40.99 and $13.49 \mathrm{~g}$, respectively), number of cut flowers per plant (8.02), per square meter (80.20) and yield of flowers (16.04 lacs/ha). Whereas, $\mathrm{GA}_{3}$ at $150 \mathrm{ppm}$ recorded the lowest number of days to the appearance of first flower bud and opening the first flower (50.98 and 57.57 days, respectively), diameter of flower $(11.37 \mathrm{~cm})$, longevity $(15.29$ days) and vase life (10.00 days). While, $\mathrm{GA}_{3}$ at $50 \mathrm{ppm}$ was found for poorest response in all parameters.

KEY WORDS : Gerbera, Gibberellic acid, Protected condition, Cut flower

HOW TO CITE THIS ARTIClE : Chauhan, R.V., Kava, K.P., Babariya, V.J., Pansuria, P.B. and Savaliya, A.B. (2014). Effect of gibberellic acid on flowering and cut flower yield in gerbera under protected condition. Asian J. Hort., 9(2) : 404-407. 